\title{
Kepastian Hukum Payment Guarantee Memitigasi Resiko Kontrak Bank dan Developer
}

\author{
Hendrik Fasco Siregar ${ }^{1 *}$, Siti Nurwulan ${ }^{1}$, Frieda Fania ${ }^{1}$ \\ Fakultas Hukum Universitas Pamulang \\ Jl. Surya Kencana No.1 Kota Tangerang Selatan 15417 Banten \\ *Email: h.fasco@gmail.com \\ Naskah diterima 21 Januari 2021, Revisi 15 Maret 2021, Terbit 29 April 2021
}

\begin{abstract}
DOI: doi.org/10.21107/pamator.v14i1.8585

The biggest risk of cooperation agreements will be experienced by Banking business actors, the specific nature of banks as credit lenders in the end requires prudence in contracting to avoid losses, payment guarantee instruments or buying back assets can be considered in the agreement system or cooperation contract. to mitigate the risk of loss to the Bank because with the buyback guarantee there is at least a special bond between the Developer and the Bank so that it will provide legal certainty. The instrument payment guarantee or asset repurchase in the deed of the cooperation agreement between the Bank and the Developer is useful for guaranteeing payment and for mitigating the risk of the Bank in the event of a bad debtor in payment, this is because the Bank cannot execute guarantees that have not been bound by the Deed of Mortgage.
\end{abstract}

Key words: bank credit, payment guarantee, risk, mitigation

\section{PENDAHULUAN}

Saat pengembang (pengembang) perusahaan yang bergerak di bidang property akan membangun dengan cara bekerjasama dengan Bank, khususnya dalam penjualan unit-unit rumah melalui fasilitas Kredit Pemilikan Rumah (KPR) kepada para Konsumen maka pihak pengembang dan Bank akan melanjutkan membuat perjanjian kerjasama yang berisi kesepakatan yang dituangkan dalam klausula perjanjian. Salah satu isi klausula tersebut adalah pihak pengembang akan memberikan jaminan-jaminan sebagaimana diatur dalam perjanjian kerjasama termasuk Payment Guarantee. Sebagaimana diketahui selama ini jaminan (collateral) ada yang bersifat kebendaan, dan bersifat perorangan dapat berupa penjamin hutang atau borgtocht (personal guarantee), jaminan perusahaan (Corporate guarantee), perikatan tanggung menanggung dan garansi bank (Bank guarantee) (Usman, 2016).

Payment Guarantee adalah jaminan pembayaran dari pengembang untuk pelunasan kewajiban debitur jika debitur melakukan wanprestasi atau disebabkan karena kelalaian sebagaimana diatur dan ditentukan dalam Perjanjian Kerjasama.
Sehingga dasar hukum keberadaan payment guarantee bukanlah karena ditentukan Undang-Undang tetapi karena perjanjian sebagai dasar hukumnya.

Pasal 1338 ayat (1) BW tersimpul asas kebebasan berkontrak, asas konsensualisme serta daya mengikatnya perjanjian. Pemahaman terhadap Pasal tersebut tidak berdiri dalam kesendiriannya, asas-asas yang terdapat dalam pasal tersebut berada dalam suatu system yang terpadu dan Integratif dengan ketentuan lainnya (Hernoko, 2014).

Senada dengan pernyataan diatas kerjasama antara Bank dengan Pengembang dalam rangka pemberian fasilitas Kredit Pemilikan Rumah (KPR) kepada Debitur termasuk perjanjian kredit yang di buat dan ditandatangani antara Bank dan Debitur pemberian fasilitas Kredit Pemilikan Rumah (KPR) untuk keperluan pembelian rumah yang dibangun oleh pengembang. Sebagai perwujudan tertulis dari perjanjian, kontrak adalah salah satu dari dua dasar hukum yang ada selain dari undang-undang yang dapat menimbulkan perikatan, seperti yang dinyatakan oleh Pasal 1233 KUH Perdata yaitu Perikatan lahir karena suatu persetujuanuan atau karena undang-undang (Satrio, 1992). 
Sebagai perwujudan dari kerjasama atau kontrak tersebut ternyata banyak pengembang gagal payment guarantee. Diantaranya di karenakan tidak mempunyai kemampuan menyelesaikan pembangunan, atau dikarenakan pengembang tidak mempunyai pengalaman. Dapat pula terjadi karena konsumen kecewa dengan kinerja pengembang terkait progres pembangunan yang tidak sesuai ekspektasi yang di harapkan oleh konsumen.

\section{METODOLOGI}

Penelitian ini dilakukan pada wilayah kabupaten Tangerang Selatan, yang merupakan salah satu Kota Provinsi Banten. Pemilihan lokasi di Kabupaten Tangerang Selatan dengan pertimbangan bahwa Pergerakan bisnis property yang dilakukan Pengembang yang melibatkan dunia Perbankan. Payment Guarantee sebagai instrument dalam perjanjian kerjasama antara Bank dengan pengembang memiliki peran yang penting dalam memitigasi resiko kerugian pada Bank sebagai penyalur kredit dalam perjanjian kerjasama antara Bank dengan pihak pengembang.

Jenis dan sumber data yang digunakan dalam penelitian ini, adalah data sekunder (secondary data) dan data primer (primary data). Data sekunder adalah data yang diperoleh peneliti dari penelitian kepustakaan dan dokumen, yang merupakan hasil penelitian dan pengolahan orang lain, yang sudah tersedia dalam bentuk buku-buku atau dokumen yang biasanya disediakan di perpustakaan, atau milik pribadi. Sedangkan yang dimaksud dengan data primer ialah data yang diperoleh langsung dari masyarakat. Dalam penelitian hukum, data sekunder mencakup bahan hukum primer, bahan hukum sekunder, dan bahan hukum tertier. Data sekunder yang digunakan dalam penelitian ini, yaitu terdiri dari UndangUndang, peraturan yang masih berlaku dan terkait.

Metode dan teknik pengumpulan data yang digunakan meliputi kepustakaan; pengamatan (observasi), wawancara (interview). Sesuai dengan sumber data seperti yang dijelaskan di atas, maka dalam penelitian ini pengumpulan data dilakukan dengan cara : studi kepustakaan, terhadap data sekunder dikumpulkan dengan melakukan studi kepustakaan, yaitu dengan mencari dan mengumpulkan serta mengkaji peraturan perundang-undangan, rancangan undang-undang, hasil penelitian, jurnal ilmiah, artikel ilmiah, dan makalah seminar yang berhubungan kepastian hukum payment Guarantee.

Wawancara (interview) di lapangan dilakukan dengan teknik wawancara tidak terarah (non-directive interview) atau tidak terstruktur (free flowing interview) yaitu dengan mengadakan komunikasi langsung kepada informan, dengan menggunakan pedoman wawancara (interview guide) guna mencari jawaban atas pelaksanaan payment gurantee. Obervasi yaitu mengadakan penelitian dengan terjun langsung pada objek yang dijadikan Sasaran untuk memperoleh sumber sumber data.

Metode analisa data yang digunakan dengan cara data yang diperoleh baik dari studi kepustakaan maupun dari penelitian lapangan akan dianalisis secara deskriptif kualitatif. Analisis deskriptif kualitatif yaitu metode analisis data yang mengelompokkan dan menyeleksi data yang diperoleh dari penelitian lapangan menurut kualitas dan kebenarannya, kemudian dihubungkan dengan teori-teori, asas-asas, dan kaidahkaidah hukum yang diperoleh dari studi kepustakaan sehingga diperoleh jawaban atas permasalahan yang dirumuskan.

\section{HASIL PEMBAHASAN \\ Payment Guarantee dan Transaksi Berjamin}

Kajian konsep jaminan dalam hukum perdata khususnya jaminan perorangan sifatnya merupakan hak perorangan bukan dan bukan merupakan hak kebendaan jaminan perorangan relatif lebih beresiko di bandingkan dengan jaminan kebendaan, oleh karenanya maka memang diperlukan sikap kehati-hatian dari pihak perbankan khususnya dalam memilih pengembang yang nantinya akan menjalin kerjasama dengan bank dalam pemberian Fasilitas Kredit Pemilikan Rumah (KPR), dalam hal ini biasanya bank akan melihat track record pengembang.

Payment Guarantee atau Buyback guarantee adalah istilah bahasa Inggris yang secara harfiah berarti jaminan membeli kembali. Sejauh ini tidak ada literature atau referensi yang menulis tentang pertama kalinya penggunaan istilah buyback 
guarantee untuk mengartikan atau jaminan dari pengembang atas kredit yang diterima oleh konsumen/debitur dari Bank dalam perjanjian kerjasama pemberian fasilitas kredit pemilikan rumah di Indonesia. Buyback guarantee sangat erat kaitannya dengan kredit pemilikan rumah (Anadi, 2019).

Kegagalan selama ini yang dialami pengembang melakukan payment guarantee atau membeli kembali objek atau asset yang telah dijual disebabkan karena dua (2) factor yaitu pertama terkait factor internal dan yang kedua factor eksternal. Faktor Internal yang menyebabkan pengembang gagal melakukan payment guarantee disebabkan pengembang tidak mempunyai kemampuan untuk menyelesaikan pembangaunan tersebut dan disebabkan pula karena konsumen kecewa karena progres pembangunan property tidak sesuai dengan ekspektasi yang di harapkan. Pengembang tidak mempunyai kemampuan untuk menyelesaikan pembangunan dapat terjadi dikarenakan pengembang tidak jujur terkait kemampuanya dalam bidang property dan dapat juga terjadi karena pengembang tidak mempunyai pengalaman dan untuk memitigasi resiko ini, Bank hendaknya harus mengandeng pengembang yang sudah berpengalaman.

Faktor kedua yang menyebabkan Pengembang gagal melakukan payment guarantee adalah terkait faktor eksternal sebagai contoh karena kondisi bencana dan berpengaruh pada kondisi ekonomi secara makro seperti yang dialami saat ini kondisi ekonomi pasca maraknya pandemi Covid19. Berkaca dari kedua factor internal dan faktor eksternal yang menyebabkan pengembang tidak dapat menjalankan kewajiban untuk melakukan payment guarantee atau membeli kembali, maka pihak Perbankan berusaha memitigasi atau mengantisipasi, hal ini disebabkan bila berpijak pada konsep perjanjian maka jaminan perorangan yang berkait erat dengan hak perorangan dan sangat tergantung dari itikad baik para pihak dan kedapannya menurut hemat penulis diharapkan adanya keharusan ketentuan khusus yang mengatur mengenai perjanjian payment Guarantee ini.

Terkait jaminan di atas beberapa Negara Common Law telah ada yang memiliki instrument transaksi berjaminan ( secured Transaction) dalam instrument transaksi berjaminan maka semua transaksi yang diikat dengan jaminan yang begitu luas diatur dalam suatu ketentuan undang-undang, sementara terkait jaminan yang ada dalam hukum perdata kita yang diatur dalam suatu ketentuan hanya jaminan kebendaan saja, sehingga untuk kedepannya ada baiknya mengikuti konsep yang ada di negara negara lain seperti di Australia (Common Law) yang telah memiliki instrument transaksi berjaminan dan diharapkan hukum perdata/ bisnis di Indonesia sedang mengarah ke sana.

Konsep transaksi berjaminan pada prakteknya dapat ditemui tentang jaminan yamg didasarkan pada perjanjian atau perorangan bila suatu saat terjadi wanprestasi terkait pengembang tidak dapat menggunakan mekanisme eksekusi dimana artinya harus melalui gugatan biasa ini akan sangat memerlukan waktu yang cukup panjang. Tapi bila seandainya jaminan ini dapat diatur dalam Undang-Undang maka terhadap jaminan tersebut dapat langsung dilakukan eksekusi terhadap aset-aset pengembang dan hal ini lebih dapat menjamin kepastian hukum. Alternatif lain yang dapat dilakukan dalam kontrak harus lebih ketat mengatur tentang kewajibankewajiban pengembang bila nantinya wanprestasi misalnya bisa di cantumkan kewajiban denda.

Konsep transaksi berjamin dilihat dari sudut perikatan lebih merupakan sautu keadaan hukum yang mengikat satu atau lebih subjek hukum dengan hak dan kewajiban timbal-balik yang berkaitan satu sama lain.Perikatan-perikatan serupa itu memang bisa lahir dari kesepakatan antara dua pihak atau lebih, atau karena UndangUndang (Kusumohamidjojo, 2019)

Menurut hemat penulis transaksi bisnis yang yang diikat dengan jaminan dan telah diatur dalam ketentuan Undang-Undang akan lebih memberikan kepastian hukum tentang hak-hak para pihak. Secara garis besar urgensinya ke depan sebaiknya semua transaksi bejamin perlu di atur dalam ketentuan Undang-Undang. Tidak hanya jaminan kebendaan saja tetapi semua jenis seluruh transaksi yang di ikat dengan jaminan termasuk pembelian kembali atau payment guarantee. Transaksi berjaminan yang akan diatur dalam ketentuan diharapkan nantinya akan lebih memberikan 
kepestian hukum bagi para pihak, sehingga bila sebelumnya debitur wanprestasi dan pengembang melakukan eksekusi harus menggunakan gugatan ke pengadilan biasa, maka akan berbeda bila jaminan kebendaan dan perorangan bisa langsung menggunakan permohonan eksekusi.

\section{Payment Guarantee sebagai Jaminan Perorangan}

Berawal dari konsep tentang jaminan secara umum, maka apabila dilihat dari jaminan secara umum yang pada intinya memiliki dua konsep yaitu jaminan umum dan jaminan khusus. Pada jaminan umum berlaku bagi semua kreditur dan semua aset atau harta benda debitur artinya tidak ada kreditur yang di dahulukan dan jaminan umum ini ada secara otomatis berdasar ketentuan undang-undang yaitu pasal 1131 KUHPerdata, jadi jaminan umum ini ada berdasarkan ketentuan undang-undang (operation of law), artinya jaminan ini otomatis ada ketika orang atau badan hukum membuat perikatan dan secara otomatis asetnya menjadi jaminan hukum sebagaimana dimaksud pada pasal 1131 sampai 1132 KUH Perdata.

Sebagaimana diketahui unsur esensial dari kredit Bank adalah adanya kepercayaan dari Bank sebagai kreditor terhadap nasabah peminjam sebagai debitur. Kepercayaan tersebut timbul karena dipenuhinya segala ketentuan dan persyaratan untuk memperoleh kredit bank oleh debitur antara lain jelasnya tujuan pemberian kredit, adanya benda jaminan atau agunan dan lain-lainya (Hermansyah, 2006).

Berbeda dengan jaminan umum apabila Kemudian masuk jaminan khusus, maka jaminan khusus dapat dibagi menjadi 2 (dua), yaitu jaminan yang terjadi berdasarkan Undang-Undang dan karena di perjanjikan para pihak dalam kontraknya, hal ini terkait benda tertentu atau orang di tunjuk sebagai penjamin, selanjutnya ada jaminan yang terjadi karena Undang-Undang dibagi menjadi 2 (dua) yaitu Hak Privilege atau hak istimewa dan Hak Retensi atau penahanan benda kedua hak tersebut memiliki kekuatan hukum secara otomatis karena ketentuan Undang-Undang.

Dalam Pasal $1132 \mathrm{KUH}$ Perdata menyebutkan barang-barang itu menjadi jaminan bersama bagi semua kreditur terhadapnya, hasil penjualan barang-barang itu dibagi menurut perbandingan utang masing-masing kecuali bila di antara para kreditur itu ada alasan-alasan sah untuk didahulukan. Pemberian jaminan dalam perjanjian kredit diharuskan dalam dunia perbankan konvensional karena pada dasarnya, sumber dana yang disalurkan berasal dari tabungan masyarakat. Dengan demikian, dana kredit yang disalurkan harus dilakukan secara hati-hati (prudent) (Purnamasari, 2011).

Secara khusus untuk jaminan kebendaan karena keberadaanya diatur dalam ketentuan undang-undang sebagaiman kita ketahui dapat berupa jaminan fidusia, gadai, hipotik, dan hak tanggungan maka jelas dan tegas mekanisme eksekusinya, walaupun dalam perkembangan terakhir banyak timbul masalah baru. Ketika berbicara jaminan perorangan maka karena sebagai penjamin yang di tunjuk itu orang atau subjek hukum sebagai penjaminnya maka tidak ada benda khusus yang dijadikan jaminan sehingga dapat meliputi semua aset penjamin.

Payment guarantee atau Buyback guarantee (jaminan pembelian kembali) yang biasa di kenal masyarakat masuk dalam jaminan khusus perorangan karena dasarnya adalah perjanjian, namun kateristiknya berbeda dengan jaminan penaggungan hutang yang selama ini kita pahami, dan hal ini perlu dipahami karena apabila dikaji dari segi jaminannya bukan ditekankan pada jaminan terhadap pembayaran hutang tetapi berupa jaminan untuk membeli kembali aset yang telah di jual, dan di sini letak perbedaaanya dengan jaminan penaggungan hutang, karena dalam jaminan penanggungan hutang maka yang dijaminkan adalah hutangya si Debitur.

Konsep Buyback guarantee yang di jaminkan adalah hutangnya si debitur yang di jamin dalam hal ini berupa jaminan pembelian kembali objek jual beli. Artinya yang di jaminkan dalam perjanjianya adalah membeli kembali barang yang sudah di jual, walaupun pada akhirnya hasil penjualannya untuk melunasi kewajiban debitur. Tapi fokus jaminan hutang bukanlah hal yang utama karena jaminan yang utama adalah membeli kembali aset yang sudah di jual.

Jaminan yang utama perjanjian antara bank dan pengembang adalah membeli kembali aset yang sudah di jual maka dapat 
disimpulkan Buyback guarantee memiliki hubungan hukum yang bersifar persfektif yaitu hubungan hukumnya terkait antara Bank dengan pengembang; antara Bank dengan Debitur dan antara pengembang dengan konsumen jadi hubungan hukumnya seperti itu. Letak jaminan pembelian kembali ini adanya di hubungan antara Bank dan pengembang.

Pada awal inisiatif dan keinginan untuk dilakukanya jaminan pembelian kembali adalah berasal dari pengembang untuk mencari dan meyakinkan Bank dalam menyediakan fasilitas KPR. Agar supaya pengembang dapat membangun perumahan atau apartemen yang nantinya akan dibeli Konsumen. Tetapi pada keadaan selanjutnya ternyata inisiatif jaminan pembelian kembali tidak hanya datang dari pengembang tetapi dari pihak Bank dengan sendirinya.

Pada salah satu karakter payment guarantee dalam perjanjian kerjasama Bank dan pengembang berguna untuk menjamin pelaksanaan perjanjian kerjasama dengan waktu yang tidak lama sekitar 3 sampai 6 bulan. Karena umumnya jaminan pembelian digunakan untuk menjamin kalau debiturnya wanprestasi sementara objek jual beli belum bisa di ikat dengan jaminan. Misalnya tanahnya masih dalam konsep sertifikat induk, sehingga belum di pecah dan biasanya bentuknya masih HGB atau Hak Guna Bangunan, karena HGB belum di pecah maka belum bisa dibuatkan akta jual belinya, sehingga belum bisa di ikat dengan jaminan hak tanggungan dan inilah yang menjadi latar belakang munculnya instrument buyback guarantee atau payment guarantee.

Pada kenyataannya payment guarantee cukup relevan dalam perjanjian kerjasama dalam jangka waktu pendek tersebut karena apabila sudah ada atau sudah dapat di ikat jaminan relatif aman bagi pihak Bank. Keberadaan payment guarantee digunakan dalam perjanjian kerjasama pada umumnya terjadi karena sertifikatnya belum di pecah, dan ternyata rumah belum di bangun atau pembangunan perumahan belum selesai, apabila dicermati pada Undang-Undang perumahan syarat keterbangunan hanya $20 \%$, jadi sudah bisa dipasarkan. Dengan syarat keterbangunan $20 \%$ itu pun banyak pengembang yang mengambil resiko, contohnya Meikarta belum 20\% pihak pengembang sudah berani memasarkan.
Konsep jaminan perorangan sifatnya adalah hak perorangan bukan hak kebendaan jadi relatif lebih beresiko di bandingkan jaminan kebendaan. Oleh karenanya maka memang diperlukan kehati-hatian dari pihak perbankan khususnya dalam memilih partner atau pengembang yang akan menjalin kerjasama dengan Bank dalam pemberian fasilitas KPR.

\section{Kepastian Hukum Payment Guarantee}

Motivasi pihak Bank dan pengembang mengunakan payment guarantee adalah untuk memitigasi resiko Bank dalam hal debitur macet pembayarannya. Hal ini disebabkan Bank belum bisa mengeksekusi jaminan karena jaminan belum diikat dengan Akta Hak Tanggungan, sehingga objeknya belum atas nama debitur. Dalam UndangUndang Nomor 10 tahun 1998 tentang perbankan dalam pasal 8 menyebutkan bahwa dalam memberikan kredit berdasarkan prinsip syariah, Bank umum wajib mempunyai keyakinan berdasarkan analisis yang mendalam atas itikad baik dan kemampuan serta kesanggupan nasabah debitur untuk melunasi hutangnya (Sutedi, 2012).

Sehingga disini payment guarantee jelas ada manfaatnya karena dengan adanya jaminan pembelian kembali setidaknya ada ikatan antar pihak Bank dan pengembang. Apabila tidak ada justru kurang memberikan kepastian hukum. Ikatan secara khusus antara pengembang dan Bank sehingga lebih memberikan kepastian hukum di bandingkan tidak ada. Bila payment guarantee tidak diepakati dalam perjanjian kerjasama Bank tidak akan memberikan kredit atau kucuran kredit hal ini disebabkan karena tidak ada jaminan bahwa debitur akan melunasi kewajibannya. Tentang apakah peraturan itu harus adil dan mempunyai kegunaan bagi masyarakatnya, adalah di luar pengutamaan nilai kepastian hukum. Nilai-nilai yang berbeda-beda tersebut, membuat penilaian kita mengenai keabsahan hukum bisa bermacam-macam. Masalah ini biasanya dibicarakan dalam hubungan dengan berlakunya hukum, suatu singkatan dari dasardasar berlakunya hukum (Wardani, 2018).

Dalam rangka mengantisipasi resiko terkait factor internal maka bank harus berhati-hati dan selektif dalam melakukan 
kerjasama dengan Pengembang dan diperlukan apa yang biasa disebut prudential banking, Bank wajib mempraktekkan prinsip kehati-hatian ini, sehingga prinsip prudential bangking harus dipahami dan kembangkan untuk memitigasi resiko Bank agar tidak mengalami kerugian, yaitu dengan cara Bank harus berhati-hati dalam memilih Pengembang, jadi Bank harus memilih Pengembang yang sudah berpengalaman dan sudah terpecaya, dan hal ini terkait dengan prinsip prudensial banking, untuk memitigasinya resiko Bank ketika Pengembang wanprestasi, dan sikap kehatihatian Bank dalam berkontrak sangat tergantung itikad baik para pihak.

Dalam Pasal 1 angka (4) PBI:11/25/2009, dijelaskan Risiko adalah potensi kerugian akibat terjadinya suatu peristiwa (event) tertentu. Pengertian Manajemen Risiko dijabarkan pada Pasal 1 angka (5): Manajemen Risiko adalah serangkaian metodologi dan prosedur yang digunakan untuk mengindentifikasi, mengukur, memantau, dan mengendalikan risiko yang timbul dari seluruh kegiatan usaha Bank, dengan demikian menurut pengertian ini, ada beberapa ukuran yang dipakai untuk mengukur risiko (Sembiring, 2012).

Faktual dalam prakteknya jaminan pembelian kembali ini beda dengan jual beli dengan hak membeli kembali. Bila dalam jual beli dengan hak membeli kembali hubungan hukumnya hanya dua pihak antara penjual dan pembeli, dan jaminan tersenuit bukan kewajiban tapi hak, hak bagi si penjual untuk membeli kembali. Sedangkan dalam jaminan pembelian kembali yang terjadi bukan hak tetapi justru kewajiban di sinlah letak perbedaanya., dan hal mini disebabkan karena Pengembang sebagai penjamin, Pengembang bukan memiliki hak tapi justru kewajiban untuk membeli kembali.

Dalam azas kebebasan berkontrak memang sepenuhnya menyerahkan kepada para pihak mengenai isi maupun bentuk perjanjian yang akan mereka buat termasuk perjanjian dalam bentuk kontrak buy back guarantee. Sebelum berkembang di Perbankan maupun lembaga leasing, pada awalnya istilah buy back guarantee secara umum terdapat dalam kontrak jual beli. Kontrak ini bisa tertulis dalam kwitansi/ nota pembelian ataupun kesepakatan secara lisan antara penjual dan pembeli. Salah satu strategi marketing biasanya dengan memberikan jaminan bahwa penjual akan membeli kembali barang yang sudah di beli oleh konsumen apabila setelah digunakan rusak atau tidak dapat dipergunakan sebagai mana mestinya dengan jangka waktu sesuai garansi. Apabila terjadi kondisi demikian, maka pembeli dapat menuntut jaminan dari penjual untuk membeli kembali barang yang telah dijamin dengan buy back guarantee (Kharisma, 2015).

Istilahkan payment guarantee lebih mirip dengan jaminan penaggungan hutang, karena yang dijaminkan adalah pembayaran hutangnya, sementara dalam payment guarantee sebenarnya yg dijamin adalah Pembelian kembali aset debitur (konsumen) walaupun pada akhirnya untuk pembayaran hutang. Konstruksi payment guarantee ini sama misalkan objek agunan telah diikat dengan jaminan, biasanya bank punya hak pengambil alih agunan, yang biasanya disebut dengan agunan yang di ambil alih. Bank akan mencari pihak ketiga yang akan membeli agunan itu. Hal ini disebabkan karena Bank hanya boleh mengambil alih agunan maksimal selama satu tahun, dan hal itu sudah diikat dengan jaminan. Sementara dalam payment guarantee/ buyback guarantee objek jaminan belum diikat dengan jaminan karena sertifikat masih atas nama pengembang, sehingga tidak bisa diikat dengan konsep agunan yang di ambil alih karena belum dapat diikat dengan jaminan.

Esensi dari payment guarantee ini adalah bukan hanya dalam konteks membeli kembali beli tetapi esensinya yang sebenarnya adalah pengakhiran atau pembatalan perjanjian pengikatan jual beli karena jual-belinya belum terlaksana. Sampai disini memang agak rumit terkait dengan konstruksi peralihan haknya. Motivasi Bank dan pengembang menggunakan payment guarantee yaitu karena hak nya belum beralih, belum ada penyerahan atau levering, sehingga belum ada penyerahan karena belum ada pembelian juga

\section{KESIMPULAN}

Istilah Payment guarantee biasanya digunakan untuk jaminan benda dan objek serta kaitannya dengan benda tetap pada intinya untuk melunasi kewajibannya 
konsumen walaupun teknisnya adalah Bank atau pengembang melakukan mengambil alih kembali objek jual belinya. Payment guarantee jelas ada manfaatnya karena dengan adanya jaminan pembelian kembali setidaknya ada ikatan antar pihak Bank dan pengembang, dan apabila tidak ada justru kurang memberikan kepastian hukum. Ikatan secara khusus antara pengembang dan Bank sehingga lebih memberikan kepastian hukum di bandingkan tidak ada. Bila payment guarantee tidak disepakati dalam perjanjian kerjasama Bank tidak akan memberikan kredit atau kucuran kredit hal ini disebabkan karena tidak ada jaminan bahwa debitur akan melunasi kewajibannya. Perlu adanya kajian lebih lanjut terkait instrument payment guarantee dan transaksi berjamin untuk memperkaya khasanah keilmuan dalam hukum perdata hukum bisnis dan perbankan.

\section{UCAPAN TERIMA KASIH}

Ucapan Terima kasih kepada Kepala LLDIKTI wilayah IV yang telah mendukung Penelitian Hibah Dikti untuk Penelitian Dosen Pemula (PDP) yang telah Penulis laksanakan.

\section{DAFTAR PUSTAKA}

Agus Yudha Hernoko, (2014). Hukum Perjanjian Asas Proporsionalitas dalam Kontrak Komersial, Prenadamedia Group, Jakarta.134.

Adrian Sutedi, Hukum Hak Tanggungan, Jakarta, Sinar Grafika, 2012.24.

Budiono Kusumohamidjojo, (2019). Perbandingan Hukum Kontrak, Mandar Maju, Bandung.13.
E.Fernando M.Manullang, (2019). Legisme, Legalitas dan Kepastian Hukum, Prenadamedia, Jakarta.

Hermansyah, (2006) Hukum Perbankan Nasional Indonesia, Predana Media Group, Jakarta.58.

Irma Devita Purnamasari,(2011) Hukum Jaminan Perbankan, PT.Mizan Pustaka, Jakarta.18.

I.Ketut Oka Setiawan, (2019) Hukum Pendaftaran Tanah dan Hak Tanggungan, Sinar Grafika, Jakarta, 85.

Racmadi Usman, (2016) Hukum Jaminan Keperdataan, Sinar Grafika,Jakarta,76.

Sentosa Sembiring,( 2012) Hukum Perbankan Edisi Revisi, Mandar Maju, Bandung.56.

Yandri Radhi Anadi, Kekuatan Hukum Akta Buy Back Guarantee dengan Kuasa Menjual Bagi Pihak Pengembang ,(2019)Jurnal Hukum dan Kenotariatan,31,2.117.

Dona Budi Kharisma, Buy Back Gurantee dan Perkembangan Hukum Jaminan Kontemporer Indonesia, (2015), Jurnal Privat Law,3,2.76.

Siti Nurwullan, Hendrik Fasco Siregar, Frieda Fania, Aspek Yuridis Perbankan sebagai Penyalur Kredit Persfektif Asa Konsesnsualime dalam Berkontrak, 8 (2020), Jurnal Pamulang Law Review,3.

Wardhani, Dwi Kusumo. "Perlindungan Hukum Terhadap Penguasaan Dan Pemilikan Hak Atas Tanah Dengan Terbitnya Seritipikat Ganda." Rechtsregel Jurnal Ilmu Hukum 1.1 (2018).39. 